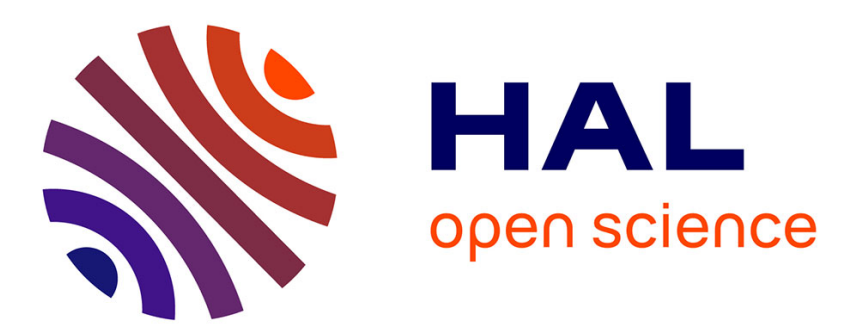

\title{
Annual contribution of different plankton size classes to particulate dimethylsulfoniopropionate in a marine perturbed ecosystem
}

Natacha Jean, Gérard Bogé, Jean-Louis Jamet, Simone Richard, Dominique Jamet

\section{To cite this version:}

Natacha Jean, Gérard Bogé, Jean-Louis Jamet, Simone Richard, Dominique Jamet. Annual contribution of different plankton size classes to particulate dimethylsulfoniopropionate in a marine perturbed ecosystem. Journal of Marine Systems, 2005, 53 (1-4), pp.235 - 247. 10.1016/j.jmarsys.2004.06.003 . hal-01885183

\section{HAL Id: hal-01885183 \\ https://hal.science/hal-01885183}

Submitted on 1 Jun 2021

HAL is a multi-disciplinary open access archive for the deposit and dissemination of scientific research documents, whether they are published or not. The documents may come from teaching and research institutions in France or abroad, or from public or private research centers.
L'archive ouverte pluridisciplinaire HAL, est destinée au dépôt et à la diffusion de documents scientifiques de niveau recherche, publiés ou non, émanant des établissements d'enseignement et de recherche français ou étrangers, des laboratoires publics ou privés. 


\title{
Annual contribution of different plankton size classes to particulate dimethylsulfoniopropionate in a marine perturbed ecosystem
}

\author{
Natacha Jean ${ }^{\mathrm{a}, *}$, Gérard Bogé ${ }^{\mathrm{b}}$, Jean-Louis Jamet ${ }^{\mathrm{b}}$, Simone Richard ${ }^{\mathrm{b}}$, Dominique Jamet ${ }^{\mathrm{b}}$ \\ a Laboratoire d'Etudes et de Recherches MArines (LERMA, EA 3202), Institut National des Sciences et Techniques de la Mer, \\ CNAM/Intechmer, Digue de Collignon, BP 324, 50103, Cherbourg cedex, France \\ ${ }^{\mathrm{b}}$ Laboratoire des PROcessus de Transfert et des Echanges en Environnement (PROTEE, EA), \\ Equipe de Biologie des Milieux Aquatiques (EBMA), Université du Sud Toulon-Var, BP 20132, 83957, La Garde cedex,
}

France

\begin{abstract}
Dimethylsulfoniopropionate (DMSP) concentrations were observed from October 1999 to September 2000 in a Mediterranean ecosystem (Little Bay of Toulon) submitted to eutrophication. DMSP was measured in the particulate material $\left(\right.$ DMSP $_{p}$ ), and more specifically in the $>90,5-90$ and $0.2-5 \mu \mathrm{m}$ fractions. DMSP was first converted into dimethylsulfide (DMS) by a cold alkali treatment. DMS was then analysed by gas chromatography equipped with a flame photometric detector (FPD). DMSP $_{\mathrm{p}}$ concentrations were relatively high, showing a strong temporal variability with maxima in February-March $(58.8 \mathrm{nM})$. The most elevated values were recorded in the 5-90 $\mu \mathrm{m}$ size class, and represented between $60 \%$ and $100 \%$ of the total DMSP $\mathrm{p}_{\mathrm{p}}$. This fraction was mostly composed of Dinoflagellates whose biomass was significantly correlated with DMSP concentrations. These concentrations showed better correlations with Ceratium furca, Dinophysis acuminata, Prorocentrum arcuatum and also Alexandrium minutum. The intracellular contents of DMSP were much higher in Dinoflagellates (124.9 \pm 5.7 $\mathrm{mM})$ than in Diatoms $(25.1 \pm 1.1 \mathrm{mM})$. A. minutum produced the strongest intracellular concentrations $(3387.6 \pm 121.9 \mathrm{mM})$. High DMSP contents were also found in D. acuminata $(477.4 \pm 64.3 \mathrm{mM})$ and P. arcuatum $(442.2 \pm 22.9 \mathrm{mM})$. The $>90 \mu \mathrm{m}$ size class had a minor importance in DMSP production, generally below $20 \%$ of the total DMSP ${ }_{\mathrm{p}}$. However, DMSP in the $>90$ $\mu \mathrm{m}$ fraction was well correlated with cladoceran abundance. Plankton cells between 0.2 and $5 \mu \mathrm{m}$ contained a low part of the DMSP $_{\mathrm{p}}$ pool, lower than $20 \%$. Besides, no correlation was found between their algal abundances and DMSP in the $0.2-5 \mu \mathrm{m}$ size class. Temperature and photoperiod could have influenced the Dinoflagellate development, and consequently, the $\mathrm{DMSP}_{\mathrm{p}}$ concentrations. The strong autumnal rains affected the composition of the phytoplankton community and the production of sulfur compounds. These particular climatic conditions have induced an increase in nutrient concentrations and a drop in salinity, which may explain the low autumnal $\mathrm{DMSP}_{\mathrm{p}}$ concentrations.
\end{abstract}

Keywords: DMSP; Mediterranean Sea; Dinoflagellates; Eutrophication

\footnotetext{
* Corresponding author. Tel.: +33 2338873 36; fax: +33 233887339 .

E-mail address: natacha.jean@cnam.fr (N. Jean).
} 


\section{Introduction}

Dimethylsulfide (DMS) is the most abundant form of volatile sulfur in the ocean. Since the 1970s, DMS has generated much interest because of its possible role in the biological regulation of the climate (CLAW hypothesis) (Lovelock et al., 1972; Charlson et al., 1987; Andreae, 1990). DMS is produced by the enzymatic cleavage of $\beta$-dimethylsulfoniopropionate (DMSP), which is an abundant compound in phytoplankton (Challenger, 1951; Ackman et al., 1966). It is widely accepted that DMSP is an osmolyte and a cryoprotectant for marine algae (Vairavamurthy et al., 1985; Dickson and Kirst, 1987; Kirst et al., 1991; Karsten et al., 1992). It has been demonstrated that DMSP could be a source of methyl groups in transmethylation reactions (Kiene et al., 1996). Recent studies also showed that DMSP and its degradation products (DMS, DMSO) could have antioxidant properties for marine phytoplankton (Steinke et al., 2002; Sunda et al., 2002; Van Rijssel and Buma, 2002).

The objective of the present study was to investigate the planktonic origin of particulate DMSP $\left(\mathrm{DMSP}_{\mathrm{p}}\right)$ in a coastal Mediterranean system perturbed by anthropogenic inputs, the Little Bay of Toulon (NW Mediterranean Sea). This ecosystem is characterized by a much higher productivity than outside of the Bay (Jamet et al., 2001; Jean, 2002). In recent decades, the Mediterranean Sea has become increasingly affected by anthropogenic activities that rise its productivity (Bethoux and Copin-Montegut, 1988).
Marine coastal areas located near cities are subjected to excessive enrichment in nutrients, resulting in eutrophication (Lacaze, 1993). This process is enhanced in enclosed or semi-enclosed bays such as Toulon Bay where nutrient dispersion is reduced (Menesguen in Barth and Fegan, 1990). In Toulon Bay, temporal evolution of $\mathrm{DMSP}_{\mathrm{p}}$ concentrations was studied during a year, in relation with plankton communities, and with some abiotic parameters such as temperature, salinity, photoperiod and nutrients concentrations.

\section{Materials and methods}

\subsection{Study site}

Toulon (central point: Latitude $43^{\circ} 05^{\prime} \mathrm{N}$ and Longitude $6^{\circ} 00^{\prime}$ E) is located on the French NW Mediterranean coast (Fig. 1). Its seaport handles a major military, commercial and tourist traffic. Toulon Bay is composed of two areas separated by a breakwater: the western basin, also called Little Bay is semi-enclosed, and the eastern basin called Large Bay is open to the sea. According to IFREMER, Little Bay is contaminated by chemical pollutants such as organic compounds (PCB, antifouling paints), heavy metals $(\mathrm{Hg}, \mathrm{Zn}, \mathrm{Pb}$ and $\mathrm{Cu}$ ) and, occasionally, by toxic plankton species such as Alexandrium minutum and Dinophysis spp. (Milano et al., 1990; Belin et al., 1995; IFREMER, 1997).

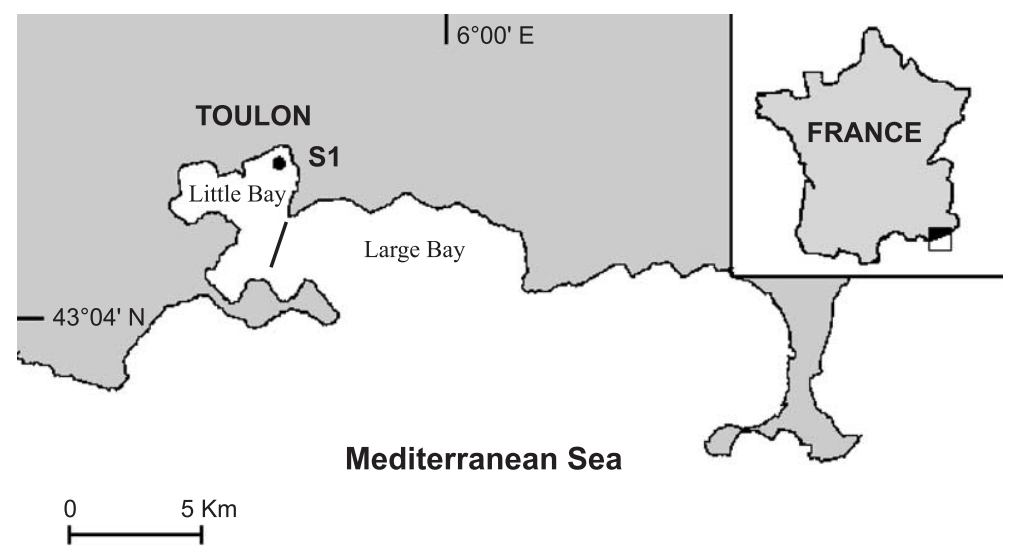

Fig. 1. Map of the Toulon area showing the sampling station (S1) in Little Bay. 


\subsection{Field sampling}

The sampling was carried out in Little Bay (S1; depth=13 m), from October 1999 to September 2000, between 9:00 and 11:00 a.m. Water samples were systematically taken from a depth of $2 \mathrm{~m}$, using a Niskin 10-1 sampling bottle. DMSP analysis was performed on a 4-1 aliquot. Ten-liter samples were taken to study the phytoplankton community but also for protein and chlorophyll $a$ determinations. Bacterial counts were made using a 50-ml subsample. Zooplankton samples were collected with a net $(0.5 \mathrm{~m}$ mouth diameter, $2.5 \mathrm{~m}$ long, $90 \mu \mathrm{m}$ mesh) equipped with a flowmeter.

\subsection{DMSP analysis}

The 4-1 water sample was successively filtered through polyamide membranes (Nytrel-TI, UGB) with 90,5 and $0.2 \mu \mathrm{m}$ pores to fractionate the particulate DMSP into size classes. Gravity filtration was applied over the $90 \mu \mathrm{m}$ membranes, a gentle pressure being used to separate the 5-90 and the $0.2-5 \mu \mathrm{m}$ fractions. The filters were stored at -80 ${ }^{\circ} \mathrm{C}$ in 15-ml hermetic polyethylene flasks. Preliminary controls indeed showed that freezing at $-80{ }^{\circ} \mathrm{C}$ had no significant effect on DMSP contents (Jean, 2002).

Before DMSP analysis, filters were first resuspended in $250 \mathrm{ml}$ cold distilled water. Then, $\mathrm{DMSP}_{\mathrm{p}}$ was converted into DMS by the cold alkali treatment method (Dacey and Blough, 1987; Turner et al., 1988). For this purpose, $\mathrm{NaOH}(10 \mathrm{M})$ was added to set the $\mathrm{pH}$ to $\sim 13$ (White, 1982; Stefels and Van Boekel, 1993). The obtained solution was transferred to a silanized glass bottle with septum and no headspace. To achieve the full transformation of DMSP into DMS, the sample was left to react in the dark at $2{ }^{\circ} \mathrm{C}$ for $24 \mathrm{~h}$. Then, the newly formed DMS was analysed following a modified method based on a cryo-trapping gas chromatographic technique (Simo et al., 1993; Simo, 1998). The gas chromatograph (DELSI 330) is equipped with a flame photometric detector (FPD) and a 1/8 in. PTFE column filled with Chromosil 330 (Supelco). Subsample volume of $5 \mathrm{ml}$ was taken from the alkaline solution with a polyethylene needle. DMS was stripped by sparging the solution with Helium (99.9996\% quality) at a flow rate of $100 \mathrm{ml} \mathrm{min}{ }^{-1}$. Then DMS was trapped onto Tenax T.A. packed at $-40{ }^{\circ} \mathrm{C}$ using magnesium perchlorate as dryer (Despiau et al., 2002). The Tenax was heated at $180{ }^{\circ} \mathrm{C}$ and DMS was injected in the column. The flame photometric detector was supplied with a flow of air $\left(F_{\mathrm{a}}=150 \mathrm{ml} \mathrm{min}{ }^{-1}\right)$ and hydrogen $\left(F_{\text {red }}=75 \mathrm{ml} \mathrm{min}^{-1} ; F_{\text {oxy }}=7 \mathrm{ml} \mathrm{min}^{-1}\right)$. Calibration was made with a DMS solution, using linear interpolation: $\ln$ (Peak area)- $\ln ($ DMS mass). Detection limit was $2 \mathrm{ng}$ and average precision of DMS concentrations was $13 \%(n=9)$. The DMSP measurements were carried out in triplicates. The average DMSP values with their standard deviations are presented.

\subsection{Phytoplankton}

\subsubsection{Enumeration}

Immediately after collection, phytoplankton of a 10-1 sample was concentrated by inverse filtration, so as to obtain a final volume of $100 \mathrm{ml}$. Then, algal cells were preserved and stored with Lugol's until further examination. Phytoplankton $>5 \mu \mathrm{m}$ was identified and counted under an inverted Nikon Diaphot microscope according to the Utermohl's method (1958) modified by Legendre and Watt (1971-1972) (total magnification $\times 400$ ). Then cell biovolumes and biomasses were estimated in accordance with the Lohman's (1908) calculation technique.

\subsubsection{Isolation of algal cells}

Monospecific phytoplankton samples were prepared from 5-1 water aliquots. Phytoplankton was first preconcentrated by inverse filtration, and then collected on $5 \mu \mathrm{m}$ pore filters. These filters were rinsed with a $38 \% 0 \mathrm{NaCl}$ solution. Phytoplankton was isolated under an inverted microscope (total magnification $\times 400$ ) using an Eppendorf pipette adjusted to $0.6 \mu \mathrm{l}$. A total of 73 Dinoflagellate cells and 177 Diatom cells were first isolated. Monospecific samples were also prepared, consisted respectively of: Dinophysis acuminata (74 cells), Ceratium furca (74 cells), Prorocentrum arcuatum (74 cells), Protoperidinium pellucidum (74 cells) and A. minutum (61 cells). The algal cells picked out, were resuspended in $20 \mathrm{ml}$ of $\mathrm{NaCl}(38 \%$ ) and stored at $-80{ }^{\circ} \mathrm{C}$ in polyethylene vials until intracellular DMSP analysis. 


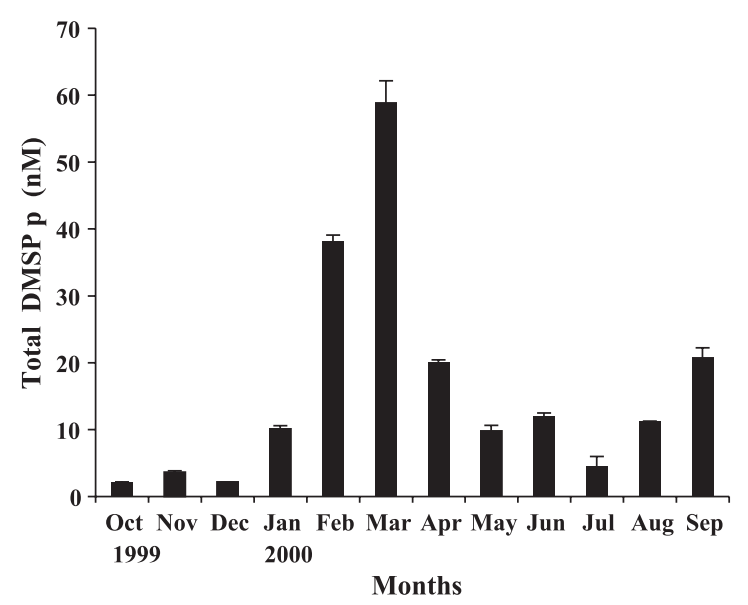

Fig. 2. Temporal changes in total $\mathrm{DMSP}_{\mathrm{p}}$ concentrations.

\subsubsection{Chlorophyll a}

The chlorophyll $a$ sample was collected on glass fibre filters (Whatman GF/C) and extracted with 90\% acetone. Then its determination was carried out according to the spectrophotometric method described by Lorenzen (1967).

\subsection{Zooplankton}

Zooplankton samples collected with the net were stored in seawater-buffered $5 \%$ formol. Aliquots for counts were taken with a Hensen pipette from the total sample adjusted to $250 \mathrm{ml}$.

\subsection{Bacteria}

Bacteria were counted by epifluorescence microscopy as described in Porter and Feig (1980). The water sample was filtered onto a black polycarbonate isopore Nuclepore filter (mesh size $0.2 \mu \mathrm{m} ; 25$ $\mathrm{mm}$ diameter). After filtration, this membrane is covered with $1 \mathrm{ml}$ of DAPI solution $\left(50 \mu \mathrm{g} \mathrm{ml}^{-1}\right)$ and left to stain in the dark. Then, the filter was observed in a dark room under an epifluorescence microscope (total magnification $\times 1000$ ) with immersion oil.

\subsection{Protein analysis}

Ten-liter samples were successively filtered through polyamide membranes (Nytrel-TI, UGB) with pore sizes of 90,5 and $0.2 \mu \mathrm{m}$ to separate the particulate material into size fractions. Proteins collected on the filters were stored at $-80{ }^{\circ} \mathrm{C}$ in $15-\mathrm{ml}$ polyethylene bottle until analysis. After resuspension in distilled water, the proteins of each fraction were analysed with Folin phenol reagent (Lowry et al., 1951). Bovine serum albumin (BSA) was used as a standard. The protein measurements were carried out in triplicates. The average protein values are presented with the standard deviations.

\subsection{Abiotic parameters}

Daily precipitation values were obtained from Météo-France for the whole year. The temperature and the salinity of seawater were measured with a WTW LF 197 electronic multi-parametric sensor at 2 $\mathrm{m}$ depth. Orthophosphates concentrations were measured according to the Murphy and Riley's method (1962) and nitrates according to Wood et al. (1967) modified by Le Poupon (1994).

\section{Results}

\subsection{Temporal evolution of $\mathrm{DMSP}_{p}$ concentrations}

The total DMSP $\mathrm{p}_{\mathrm{p}}$ contents ranged from $2.1 \mathrm{nM}$ in October to $58.8 \mathrm{nM}$ in March (Fig. 2). The temporal

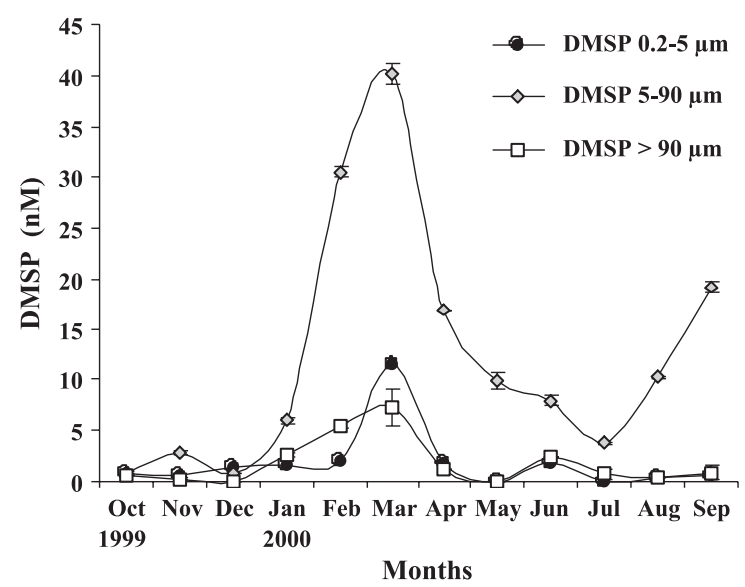

Fig. 3. Temporal changes in DMSP concentrations in the $>90,5-90$ and $0.2-5 \mu \mathrm{m}$ size classes. 


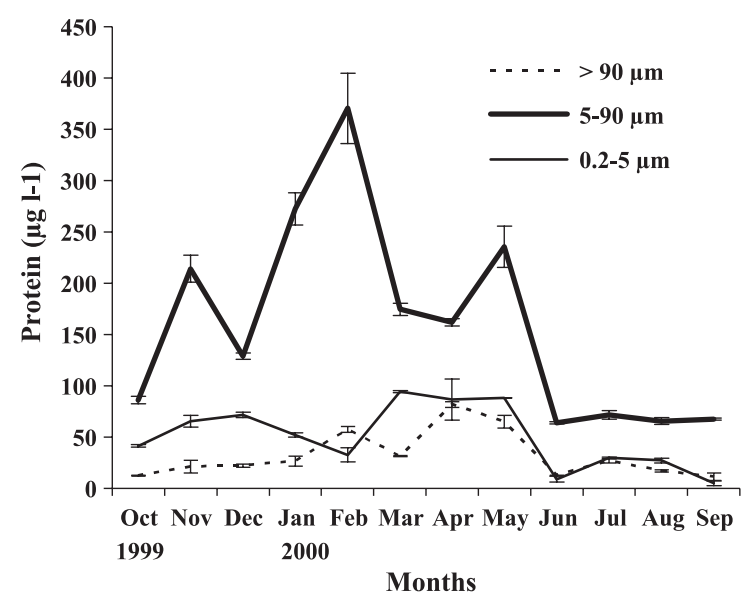

Fig. 4. Temporal changes in the protein concentrations in the $>90$, 5-90 and $0.2-5 \mu \mathrm{m}$ size classes.

variations showed a marked seasonal influence with high levels in February-March.

DMSP was also analysed in the $>90,5-90$ and $0.2-5 \mu \mathrm{m}$ fractions (Fig. 3). The highest concentrations (40 $\mathrm{nM}$ in March) were recorded for the 5-90 $\mu \mathrm{m}$ fraction. The contribution of this size class ranged between $60 \%$ and $100 \%$, except in October and December when it did not exceed $40 \%$. In the three size classes, DMSP contents followed the same trend, with peaks in February-March. Moreover, high levels existed in August and September for the 5-90 $\mu \mathrm{m}$ fraction.

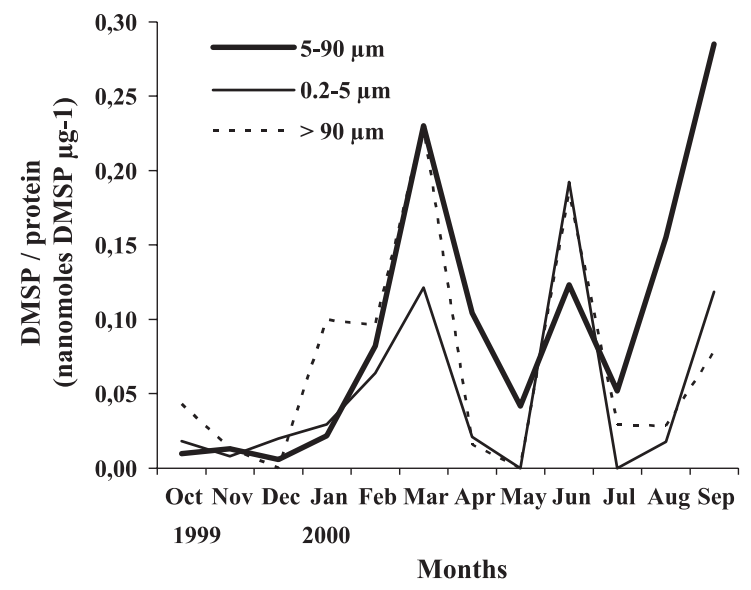

Fig. 5. Temporal changes in the DMSP/protein ratio in the $>90$, 5-90 and $0.2-5 \mu \mathrm{m}$ size classes.

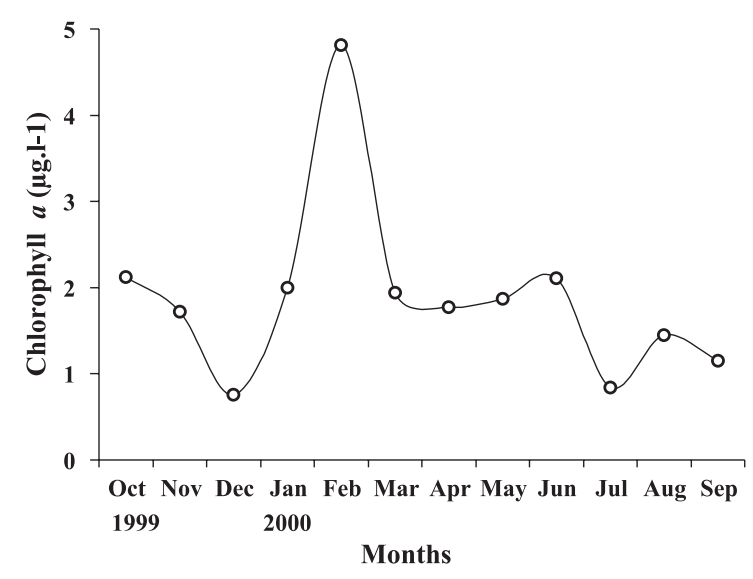

Fig. 6. Temporal variations of chlorophyll $a$ concentrations.

\subsection{Relationships with biotic parameters}

\subsubsection{Proteins}

The 5-90 $\mu \mathrm{m}$ fraction, collecting the main part of DMSP pool, also contained the highest protein
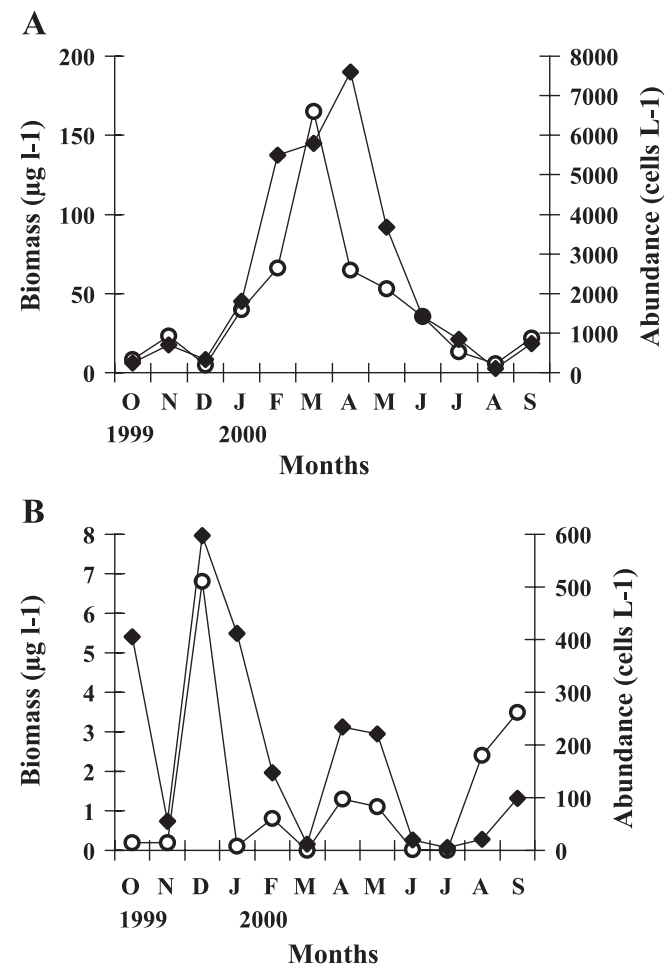

Fig. 7. Temporal variations in the abundance $(\diamond)$ and biomass $(O)$ of Dinoflagellates (A) and Diatoms (B). 
contents (Fig. 4). They ranged from 64.0 to $370.5 \mu \mathrm{g}$ $1^{-1}$, whereas they were between 9.0 and $94.5 \mu \mathrm{g} 1^{-1}$ in the other fractions. Like DMSP, protein concentrations of the 5-90 $\mu \mathrm{m}$ fraction increased from January and peaked in February. Then, they decreased until July, when the lowest levels were recorded.

For the $>90 \mu \mathrm{m}$ size class, the highest protein concentrations were found in April-May, and between March and May for the smallest $0.2-5 \mu \mathrm{m}$ size class. The DMSP/protein ratio was also calculated (Fig. 5). For the three fractions, it showed a similar temporal variability, with peaks in March, June and September and comparable levels.
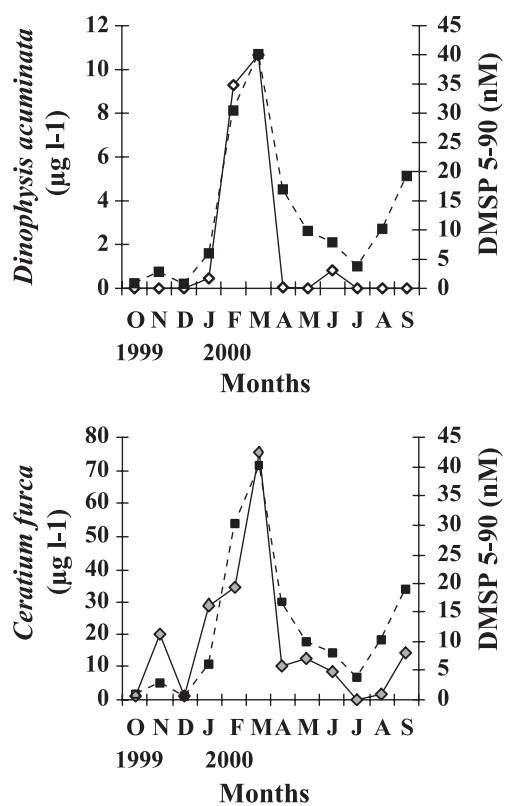

Table 1

Intracellular concentrations of DMSP in Dinoflagellates and Diatoms

\begin{tabular}{lc}
\hline Dinoflagellates & $14.2 \pm 0.6 \mathrm{pmol} \mathrm{cell}^{-1}$ \\
& $124.9 \pm 5.7 \mathrm{mM}$ \\
Diatoms & $2.7 \pm 0.1 \mathrm{pmol} \mathrm{cell}$ \\
& $25.1 \pm 1.1 \mathrm{mM}$ \\
\hline
\end{tabular}

\subsubsection{Chlorophyll a}

The chlorophyll a concentrations followed a marked seasonal trend, with high levels in February (Fig. 6). This biotic parameter is thus related to the DMSP concentrations in the 5-90 $\mu \mathrm{m}$ class.

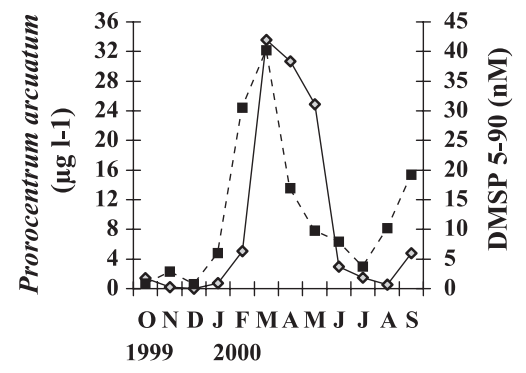

Months
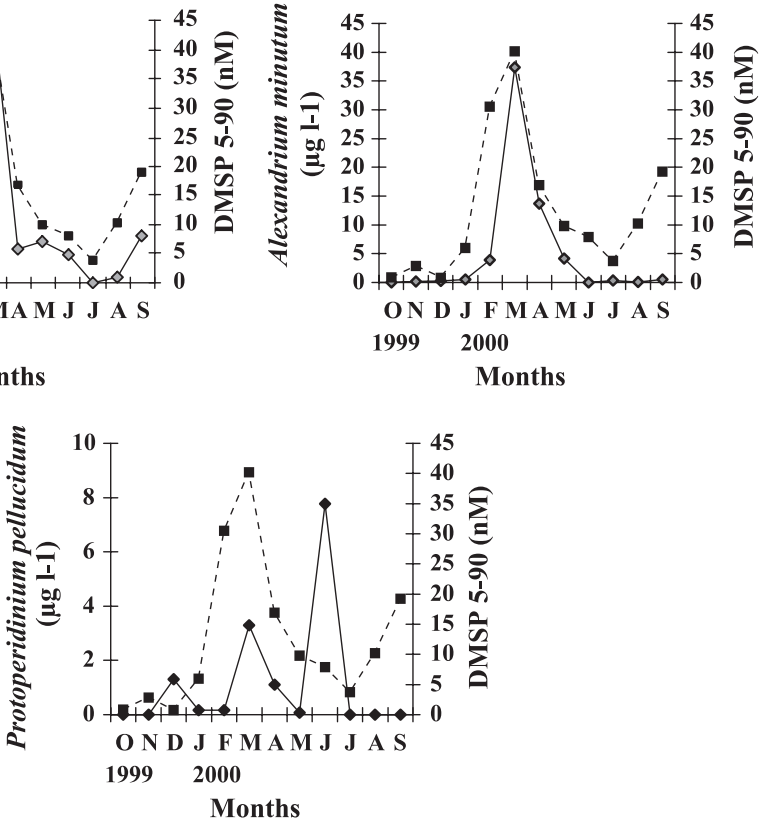

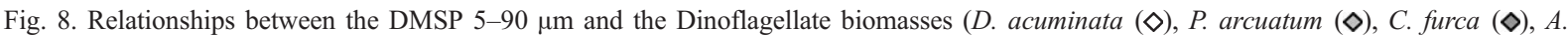
minutum $(\diamond)$ and Proto. pellucidum $(\diamond))$. 
Table 2

Intracellular concentrations of DMSP in five Dinoflagellates

\begin{tabular}{lc}
\hline D. acuminata & $14.7 \pm 1.9 \mathrm{pmol} \mathrm{cell}^{-1}$ \\
C. furca & $477.4 \pm 64.3 \mathrm{mM}$ \\
& $9.8 \pm 0.6 \mathrm{pmol} \mathrm{cell}$ \\
& -1 \\
A. minutum & $37.5 \pm 2.1 \mathrm{mM}$ \\
& $14.2 \pm 0.5 \mathrm{pmol} \mathrm{cell}$ \\
& \\
P. arcuatum & $3387.6 \pm 121.9 \mathrm{mM}$ \\
& $13.5 \pm 0.7 \mathrm{pmol} \mathrm{cell}^{-1}$ \\
P. pellucidum & $442.2 \pm 22.9 \mathrm{mM}$ \\
& $14.7 \pm 1.5 \mathrm{pmol} \mathrm{cell}^{-1}$ \\
& $133.5 \pm 13.5 \mathrm{mM}$ \\
\hline
\end{tabular}

\subsubsection{Phytoplankton community}

The 5-90 $\mu \mathrm{m}$ fraction was principally composed of Dinoflagellates and Diatoms (Fig. 7). Dinoflagellates

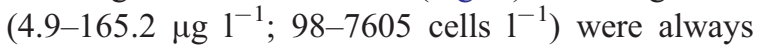
predominant in comparison to Diatoms $(0.1-6.8 \mu \mathrm{g}$ $1^{-1} ; 5-597$ cells $1^{-1}$ ). Dinoflagellate biomass and abundance peaked in March and April, whereas Diatom biomass and abundance developed from October to December. A significant correlation existed between Dinoflagellate biomass and DMSP concentration of the 5-90 $\mu \mathrm{m}$ size class (Spearman

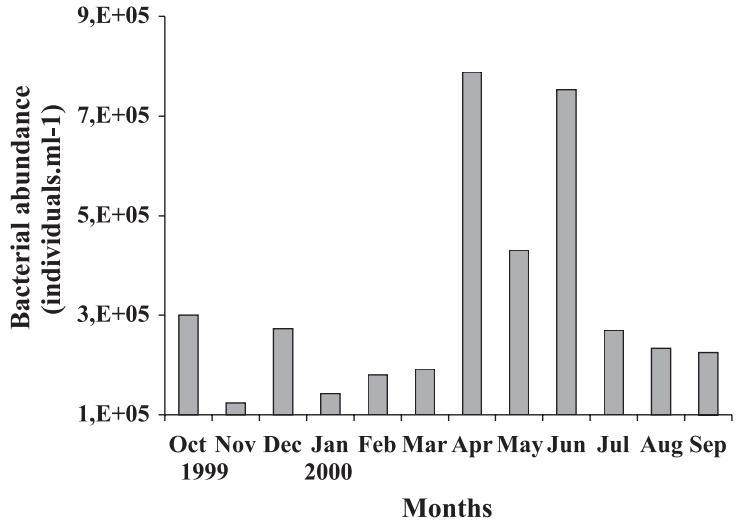

Fig. 10. Temporal variations of the bacterial abundance.

test: $r=0.699 ; p=0.011$ ) (Fig. 8). Correlations were also found with the biomass of specific algae such as C. furca $(r=0.560 ; p=0.052) ; D$. acuminata $(r=0.555 ; p=0.055) ; P$. arcuatum $(r=0.545$; $p=0.059)$, whereas a relation $(0.05<p<0.1)$ was noticed with $A$. minutum.

In order to specify the contribution of these species to DMSP production, DMSP has been analysed on
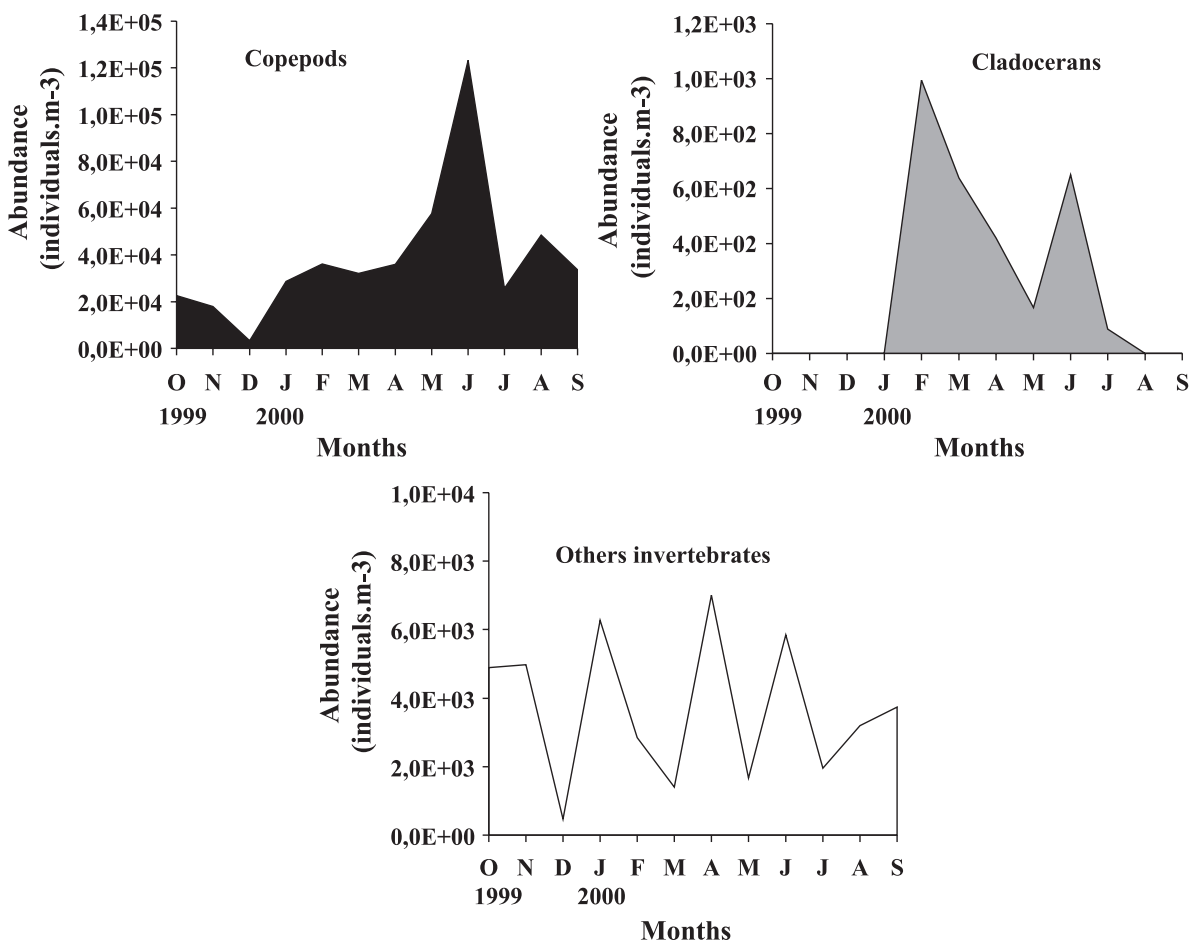

Fig. 9. Temporal variations in the abundance of copepods, cladocerans and of others invertebrates. 


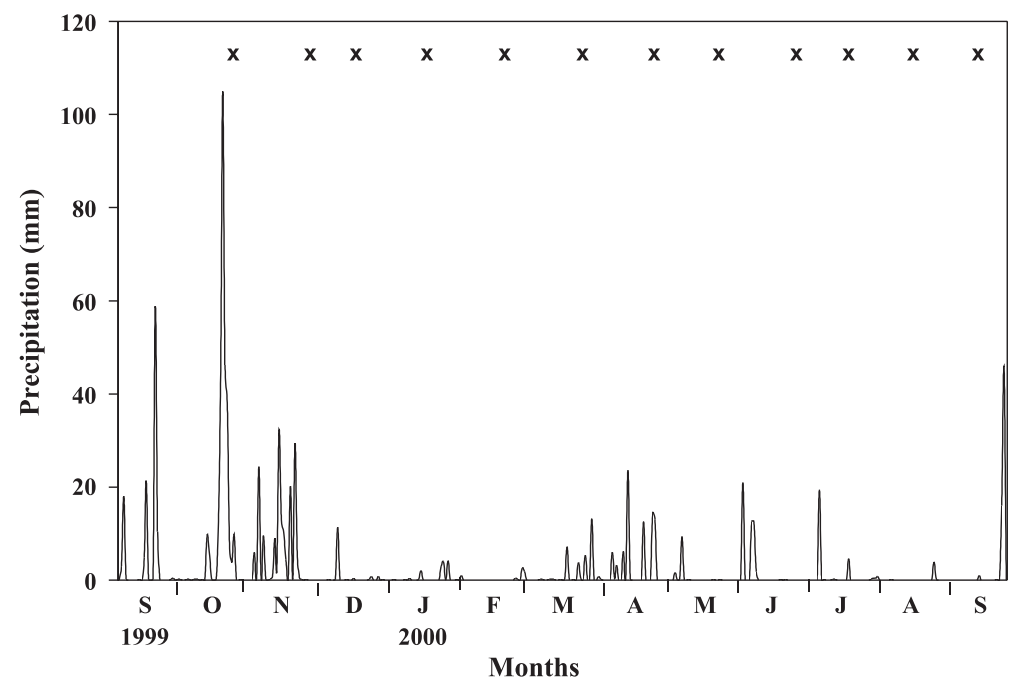

Fig. 11. Daily variations in rainfall in the Toulon area ( $\times$ : sampling dates).

isolated cells. Table 1 shows that a Dinoflagellate cell hold about five times more DMSP $(14.2 \pm 0.6 \mathrm{pmol}$ cell $\left.^{-1}\right)$ than a Diatom cell $\left(2.7 \pm 0.1 \mathrm{pmol}^{\text {cell }}{ }^{-1}\right)$. The intracellular DMSP contents per unit of cell biovolume were always five times higher in Dinoflagellates $(124.9 \pm 5.7 \mathrm{mM})$ than in Diatoms $(25.1 \pm 1.1 \mathrm{mM})$. Among Dinoflagellates, the amounts of DMSP per cell were markedly similar, reaching between 10 and $15 \mathrm{pmol} \mathrm{cell}^{-1}$ (Table 2). However, the intracellular DMSP concentrations expressed per unit of cell volume were much more contrastive. The highest contents were encountered in A. minutum (3387.6士 $121.9 \mathrm{mM})$ and in D. acuminata $(477.4 \pm 64.3 \mathrm{mM})$ and the lowest in $C$. furca.

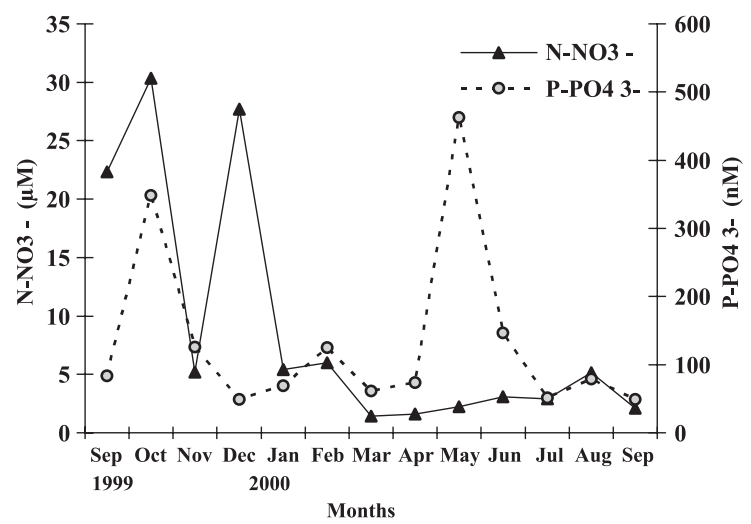

Fig. 12. Temporal variations of nitrate and orthophosphate concentrations.

\subsubsection{Zooplankton community}

The $>90 \mu \mathrm{m}$ fraction was mainly consisted of zooplankton organisms (Fig. 9). Copepods were numerically dominant (from $78 \%$ to $97 \%$ ), especially in June $\left(1.3 \mathrm{e}+5\right.$ ind $\left.\mathrm{m}^{-3}\right)$. But no correlation existed with the DMSP concentration in the $>90$ fraction. In return, a significant correlation was noticed with cladoceran abundance $(r=0.587 ; p=0.042)$. Cladocerans were a minority in Toulon Bay and were observed in February $\left(1000\right.$ ind $\left.\mathrm{m}^{-3}\right)$ and June $\left(600\right.$ ind $\left.\mathrm{m}^{-3}\right)$.

\subsubsection{Bacterial abundance}

The bacterial abundance remained low during the major part of the year, except in April, May

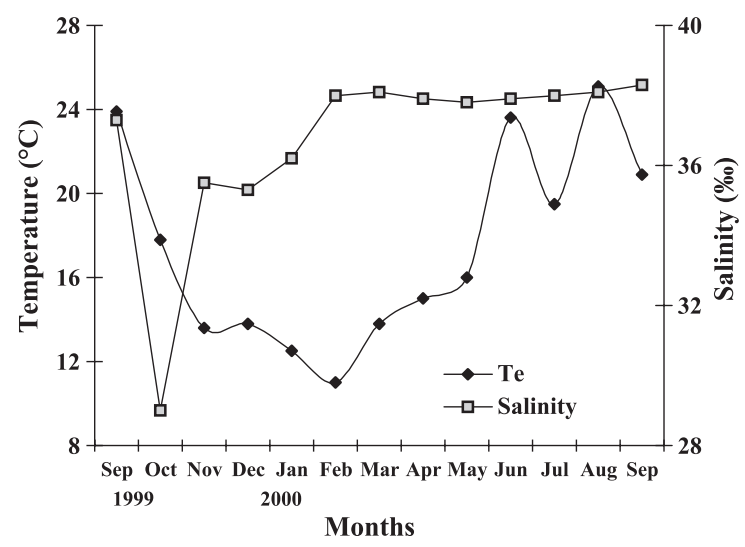

Fig. 13. Annual variations of temperature and salinity. 


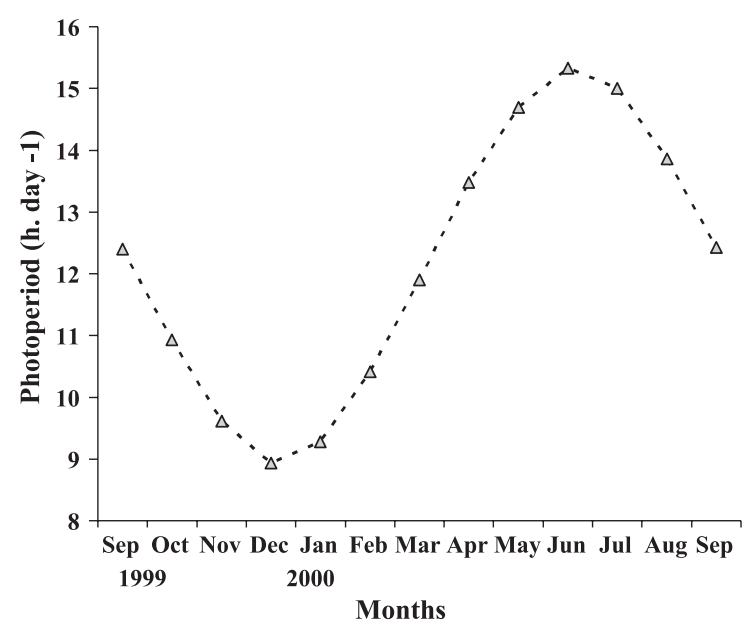

Fig. 14. Temporal evolution of photoperiod.

and June, with a maxima around $8 \mathrm{e}+5$ ind $\mathrm{ml}^{-1}$ (Fig. 10). No significant correlation was observed with the particulate DMSP of the $0.2-5 \mu \mathrm{m}$ size class.

\subsection{Relationships with abiotic parameters}

The rainfall pattern in Toulon area was characterized by a high temporal variability (Fig. 11). In autumn, precipitations occurred in the form of strong showers (105 mm on 19 October 1999). These rains greatly affected the nutrient concentrations (Fig. 12), which were highly increased in October (up to 30.3 $\mu \mathrm{M}$ for nitrates and to $348 \mathrm{nM}$ for orthophosphates), but also the salinity which dropped to $29 \%$ o (Fig. 13). This period was characterized by high Diatom abundances and low $\mathrm{DMSP}_{\mathrm{p}}$ concentrations. From February to September, salinity gradually stabilized at around $38 \%$. Photoperiod started to increase from December (Fig. 14). Seawater temperature increased later, in February (Fig. 13). In the same time, DMSP concentrations and Dinoflagellate abundances began to rise.

\section{Discussion}

Since CLAW hypothesis has been expressed, many oceanographic missions have been dedicated to the sulphur cycle (DMS, DMSP) in global oceans (Kettle, 1999). However, only few works have been carried out in shallow and coastal ecosystems. Influence of anthropogenic inputs on these specific areas has rarely been studied. This work was performed in the Little Bay of Toulon, in order to analyse the variations of DMSP $_{p}$ in relation with plankton communities and environmental parameters.

For this purpose, $\operatorname{DMSP}_{\mathrm{p}}$ was measured in different plankton size classes. Bates et al. (1994) mentioned that the $\mathrm{DMSP}_{\mathrm{p}}$ concentrations may be underestimated when the filtering pressure results in cell rupture. Ideally, only gravity filtration would prevent the loss of $\mathrm{DMSP}_{\mathrm{p}}$. In this study, gravity filtration was applied over the $90 \mu \mathrm{m}$ membranes, whereas a gentle pressure should be used to separate the 5-90 and $0.2-5 \mu \mathrm{m}$ fractions. Some authors pointed out the reproducible character of the losses of $\mathrm{DMSP}_{\mathrm{p}}$ by filtration, and recommended the use of correction factors (Stefels and Van Boekel, 1993). To estimate the losses due to filtration, we carried out experiments with the 5-90 $\mu \mathrm{m}$ fraction. These losses were estimated at $37.3 \pm 7.9 \%(n=4)$, meaning that the $\mathrm{DMSP}_{\mathrm{p}}$ data presented here were probably underestimated.

The $\mathrm{DMSP}_{\mathrm{p}}$ concentrations are generally more elevated in coastal waters than in open sea (Kiene and Linn, 2000). It is also the case in Toulon Bay where high $\mathrm{DMSP}_{\mathrm{p}}$ concentrations were found, ranging from 2.1 to $58.8 \mathrm{nM}$. At Villefranche-sur-mer, in the Mediterranean Sea, Belviso et al. (1990) mentioned similar concentrations in order of $65 \mathrm{nM}$, which are in accordance with our results. Much more elevated values (between 3.4 and $4.7 \mu \mathrm{M}$ ), were observed in the Barcelona harbour (Belviso et al., 2000). Previous measurements performed in our laboratory showed much lower DMS and $\mathrm{DMSP}_{\mathrm{p}}$ levels outside of the Bay of Toulon (Despiau et al., 2002; Jean, 2002). This contrast is probably due to the semi-enclosed and coastal configuration of the Bay which may influence a stronger algal productivity and consequently, higher DMSP $_{\mathrm{p}}$ levels.

According to Liss et al. (1993), temporal profile of DMSP concentrations is defined by a strong seasonality in temperate waters, particularly in coastal areas. In Toulon, the $\mathrm{DMSP}_{\mathrm{p}}$ concentrations followed an obvious seasonal evolution, with a maximum which is 28 times greater than the minimum. This maximum was observed in winter, whereas in other areas, it is generally found in springtime, particularly in the 
Wadden Sea (Van Duyl et al., 1998) and in the Sargasso Sea (Dacey et al., 1998).

In open-ocean surface waters, most of DMSP is found in suspended particles whose size ranges from tenths to several hundreds of microns (Turner et al., 1988). In Toulon, the highest DMSP contents were measured in the 5-90 $\mu \mathrm{m}$ fraction. This is in good agreement with the results of Belviso et al. (2000) in Barcelona harbour, who found more than $90 \%$ of total $\mathrm{DMSP}_{\mathrm{p}}$ in the $>10 \mu \mathrm{m}$ fraction. According to Corn et al. (1996), picoplanktonic DMSP represented only $10 \%$ of the total DMSP $_{\mathrm{p}}$ in the Ligurian Sea and up to $25 \%$ in Atlantic Ocean.

It has often been shown in the literature that chlorophyll $a$ data were not coupled to biomass and also not to $\operatorname{DMS}(\mathrm{P})$, on account of algal species differences. In this work, we estimated the plankton biomass in each particulate fraction using the protein contents. In Toulon Bay, the 5-90 $\mu \mathrm{m}$ fraction held the highest protein concentrations. This suggests that the elevated DMSP values in the 5-90 $\mu \mathrm{m}$ size class were due to the greater contribution of this fraction to the plankton biomass. To check this assumption, we have calculated the DMSP/protein ratio for this size class. Its strong temporal variations, with increases in March, June and September, mean that the DMSP values found in the 5-90 $\mu \mathrm{m}$ size class cannot fully be explained by the biomass in this fraction. Such temporal evolution of this ratio suggests that some planktonic organisms produce large amounts of DMSP at some periods of the year. This hypothesis has been confirmed by DMSP measurements on isolated cells of the 5-90 $\mu \mathrm{m}$ fraction. In Toulon, this size class was principally composed of Diatoms and Dinoflagellates. But the isolation of algal cells showed the major role of Dinoflagellates in DMSP concentrations. These organisms contained higher intracellular concentrations of DMSP $(124.9 \pm 5.7 \mathrm{mM})$ than Diatoms $(25.1 \pm 1.1 \mathrm{mM})$. These values are in accordance with Turner et al. (1988), who showed that the intracellular DMSP can vary between 37 and 95 $\mathrm{mM}$ in phytoplankton. It is generally accepted that Prymnesiophytes (including coccolithophorids) and Dinoflagellates contain more DMSP than do Diatoms (Keller et al., 1989; Liss et al., 1993). According to Keller and Korjeff-Belows (1996), Dinoflagellates produce several hundreds of millimoles DMSP per unit cell volume. Belviso et al. (2000) measured values ranging from 355 to $972 \mathrm{mM}$ in Dinoflagellates and Turner et al. (1988) found concentrations of $650 \mathrm{mM}$ in Flagellates.

In Toulon Bay, among Dinoflagellates, P. arcuatum, C. furca, D. acuminata and especially $A$. minutum contributed considerably to DMSP production. Their biomasses are well correlated with temporal evolution of DMSP concentrations in the 5-90 $\mu \mathrm{m}$ class. The intracellular DMSP content was particularly high in A. minutum $(3387.6 \pm 121.9 \mathrm{mM})$. In the other Dinoflagellates, it ranged between $37.5 \pm 2.1 \mathrm{mM}$ (C. furca) and 477.4 $\pm 64.3 \mathrm{mM}$ (D. acuminata). Using these values together with the phytoplankton abundances, we estimated that these species were responsible for until $70 \%$ of the total DMSP $_{\mathrm{p}}$ in March.

A. minutum is well known to produce Diarrheic Shellfish Poison (DSP) toxins (Sournia et al., 1991; Lassus et al., 1995). This species is commonly associated with algae proliferation due to the eutrophication (Menesguen in Barth and Fegan, 1990; Souchu and Aminot in IFREMER, 2001a). Its presence in Toulon Bay was confirmed by the «réseau seau francais de surveillance des efflorescences algales» from IFREMERd (2001b). Alexandrium genus grows generally better in nitrogen-rich ecosystems with a limited supply of phosphate (Wang and Hzieh, 2002). It also could be the case in Toulon Bay, where high nitrate concentrations and high values of the $\mathrm{N} / \mathrm{P}$ ratio preceded the bloom of $A$. minutum. However, photoperiod could also have an important role, since Alexandrium growth started when the photoperiod began to increase.

In this work, we also found that DMSP of the $>90$ $\mu \mathrm{m}$ size class was correlated with the cladoceran abundance. The role of zooplankton in the sulphur cycle has often been mentioned in the literature. Dacey and Wakeham (1986) showed that the third of the algal DMSP grazed by zooplankton organisms was released as DMS in the culture medium. But the most part of the DMSP ingested by Eurytemora affinis is excreted as faecal pellets, without being metabolized (Kwint et al., 1996). Besides, according to Tang (2000), the rate of DMSP not assimilated by Acartia tonsa is between $88 \%$ and $100 \%$. It is now largely accepted that the presence of DMSP in zooplankton organisms is only due to the ingestion of algal cells. In Toulon Bay, the correlation between 
cladocerans and DMSP may confirm this idea. Indeed, cladocerans are grazers, whereas copepods are rather omnivorous (Bougis, 1974).

Regarding the last size fraction, no correlation was found between the DMSP concentrations of the $0.2-5 \mu \mathrm{m}$ class and the bacterial abundance. Bacterial growth occurred mainly between April and June, whereas DMSP concentrations in the $0.2-5 \mu \mathrm{m}$ fraction increased earlier, in March. This suggest that, in the $0.2-5 \mu \mathrm{m}$ size class, DMSP comes probably from phytoplankton rather than bacteria.

The Little Bay of Toulon is characterized by a higher algal abundance than in open sea. However, no anoxia was recorded, and nutrient concentrations were only episodically high. The semi-enclosed Toulon Bay is influenced by rains, which result in increased nutrients concentrations and falls in salinity. The low salinity observed in autumn may explain the low values of $\mathrm{DMSP}_{\mathrm{p}}$ concentrations and of the DMSP/ protein ratio recorded in this season. Indeed, DMSP is an osmolyte protecting algal cells against external strong salinities. Hypo-osmotic conditions observed in October may have induced cell lysis but also a decrease in DMSP synthesis.

Finally, this study indicated that high concentrations of $\mathrm{DMSP}_{\mathrm{p}}$ existed in the Little Bay of Toulon. They come from high algal abundances and more precisely from Dinoflagellates. They also result of the presence of DMSP-rich species, and especially of $A$. minutum. Such particularities are probably due to the configuration of the Bay which limits the exchanges with outside and makes it particularly sensible to abiotic factors such as precipitations. So, this work brings an indirect contribution for a better understanding of the influence and the consequences of eutrophication on the natural sulphur cycle.

\section{Acknowledgments}

The authors thank the Institut Universitaire de Technologie of the Université de Toulon et du Var (Director of IUT: Prof. Bruno Rossetto) and the Département de Génie Biologique for technical support (Head of Department: Prof. Michel Camail).

\section{References}

Ackman, R.G., Tocher, C.S., Mac Lachlan, J., 1966. Occurrence of dimethyl- $\beta$-propiothetin in marine phytoplankton. J. Fish. Res. Board Can. 23, 357-364.

Andreae, M.O., 1990. Ocean-atmosphere interactions in the global biogeochemical sulfur cycle. Mar. Chem. 30, 1-29.

Barth, H., Fegan, L., 1990. Eutrophication-related phenomena in the Adriatic Sea and in other Mediterranean coastal zones. Water Pollut. Res. 16, 255.

Bates, T.S., Kiene, R.P., Wolfe, G.V., Matrai, P.A., Buck, K.R., Blomqist, B.W., Cuhel, R.L., 1994. The cycling of sulphur in surface seawater of the northeast Pacific. J. Geophys. Res. 99, $7835-7843$.

Belin, C., Beliaeff, B., Raffin, B., Rabia, M. Ibanez, F., 1995. Phytoplankton time-series data of the French phytoplankton monitoring network: toxic and dominant species. In: Lassus, P., Arzul G., Erard E., Gentien, P., Marcaillou, C. (Eds.), Harmful Marine Algal Blooms. Technique et Documentation Lavoisier, Intercept.

Belviso, S., Kim, S.K., Rassoulzadegan, F., Krajka, B., Nguyen, B.C., Mihalopoulos, N., Buat-Menard, P., 1990. Production of DMSP and DMS by a microbial food web. Limnol. Oceanogr. $35,1810-1821$.

Belviso, S., Christaki, U., Vidussi, F., Marty, J.C., Vila, M., Delgado, M., 2000. Diel variations of the DMSP-to-chlorophyll ratio in Northwestern Mediterranean surface waters. J. Mar. Syst. 25, 119-128.

Bethoux, J.P., Copin-Montegut, G., 1988. Phosphorus and nitrogen in the Mediterranean Sea: specificities and forecasting. In: Minas, H.J., Nival, P. (Eds.), Océanographie Pélagique Méditerranéenne. Oceanologica Acta, pp. 75-78. Special Issue.

Bougis, P., 1974. Ecologie du plancton marin: II. Le zooplancton. Collect. Ecol. 3, 200. Masson (Editors).

Challenger, F., 1951. Biological methylation. Adv. Enzymol. 12, 429-491.

Charlson, R.J., Lovelock, J.E., Andreae, M.O., Warren, S.G., 1987. Oceanic phytoplankton, atmospheric sulfur, cloud albedo and climate. Nature 326, 655-661.

Corn, M., Belviso, S., Partensky, F., Simon, N., Christaki, U., 1996. Origin and importance of picoplanktonic DMSP. In: Kiene, R.P., Visscher, P.T., Keller, M.D., Kirst, G.O. (Eds.), Biological and Environmental Chemistry of DMSP and Related Sulfonium Compounds. Plenum, New York, pp. 191-201.

Dacey, J.W.H., Wakeham, S.G., 1986. Oceanic dimethylsulfide: production during zooplankton grazing on phytoplankton. Science 233, 1314-1316.

Dacey, J.W.H., Blough, N.V., 1987. Hydroxide decomposition of DMSP to form DMS. Geophys. Res. Lett. 14, 1246-1249.

Dacey, J.W.H., Howse, F.A., Michaels, A.F., Wakeham, S.G., 1998. Temporal variability of dimethylsulfide and dimethylsulfoniopropionate in the Sargasso Sea. Deep Sea Res. I 45, 2085-2104.

Despiau, S., Gourdeau, J., Jamet, D., Geneys, C., Jamet, J.L., 2002. Seawater DMS in a perturbed coastal ecosystem. Hydrobiologia 489, 107-115. 
Dickson, D.M.J., Kirst, G.O., 2001. Osmotic adjustment in marine eukaryotic algae: the role of inorganic ions, quaternary ammonium, tertiary sulphonium and carbohydrate solutes: II. Prasinophytes and haptophytes. New Phytol. 106, 657-666.

IFREMER, 1997. La surveillance de la qualité des eaux côtières à l'IFREMER. IFREMER Internal Report, DEL/97-10/, Issy les Moulineaux, p. 21.

IFREMER, 2001a. L'eutrophisation des eaux marines et saumâtres en Europe, en particulier en France. Report for the European Commission, DG.ENV.B1. IFREMER, Issy les Moulineaux. p. 59 .

IFREMER, 2001b. Résultats de la surveillance de la qualité du milieu marin littoral. Laboratoire côtier Toulon-La Seyne. IFREMER, Issy les Moulineaux. p. 34.

Jamet, J.L., Boge, G., Richard, S., Geneys, C., Jamet, D., 2001. The zooplankton community in bays of Toulon area (northwest Mediterranean Sea France). Hydrobiologia 457, 155-165.

Jean, N., 2002. Etude du DMSP et du DMS dans deux écosystèmes littoraux marins de niveaux trophiques différents (Méditerranée Occidentale, France): relations avec les facteurs abiotiques et biotiques. PhD thesis, Univ. Toulon et du Var, France, p. 283.

Karsten, U., Wiencke, C., Kirst, G.O., 1992. Dimethylsulfoniopropionate (DMSP) accumulation in green macroalgae from polar to temperate regions: interactive effects of light versus salinity and light versus temperature. Polar Biol. 12, 603-607.

Keller, M.D., Korjeff-Belows, W., 1996. Physiological aspects of the production of dimethylsulfoniopropionate (DMSP) by marine phytoplankton. In: Kiene, R.P., Visscher, P.T., Keller, M.D., Kirst, G.O. (Eds.), Biological and Environmental Chemistry of DMSP and Related Sulfonium Compounds. Plenum, New York, pp. 131-142.

Keller, M.D., Bellows, W.K., Guillard, R.R.L., 1989. Dimethylsulfide production in marine phytoplankton. In: Saltzman, E.S., Cooper, W.J. (Eds.), Biogenic Sulfur in the Environment. American Chemical Society, Washington, D.C., pp. 167-182.

Kettle, A.J., 1999. A global database of sea surface dimethylsulfide (DMS) measurements and a procedure to predict sea surface DMS as a function of latitude, longitude, and month. Glob. Biogeochem. Cycles 13, 399-444.

Kiene, R.P., Linn, L.J., 2000. Distribution and turnover of dissolved DMSP and its relationship with bacterial production and DMS in the Gulf of Mexico. Limnol. Oceanogr. 45, 849-861.

Kiene, R.P., Visscher, P.T., Keller, M.D., Kirst, G.O., 1996. Biological and Environmental Chemistry of DMSP and Related Sulfonium Compounds. Plenum, New York, p. 430.

Kirst, G.O., Thiel, C., Wolff, H., Nothnagel, J., Wanzek, M., Ulmke, R., 1991. Dimethylsulfoniopropionate (DMSP) in ice algae and its possible biological role. Mar. Chem. 35, 381-388.

Kwint, R.L.J., Irigoien, X., Kramer, K.J.M., 1996. Copepods and DMSP. In: Kiene, R.P., Visscher, P.T., Keller, M.D., Kirst, G.O. (Eds.), Biological and Environmental Chemistry of DMSP and Related Sulfonium Compounds. Plenum, New York, pp. $239-252$.

Lacaze, J.C., 1993. La dégradation de l'environnement côtier: Conséquences écologiques. Collections Sciences de l' Environment, Masson, Paris.
Lassus, P., Arzul, G., Erard, E., Gentien, P. Marcaillou, C., 1995. Phytoplankton time-series data of the French phytoplankton monitoring network: toxic and dominant species. In: Belin, C., Bellaeff, B., Raffin, B., Ibanez, F., Rabla, M. (Eds.), Harmful Marine Algal Blooms, Technique et Documentation, Lavoisier, Intercept, Paris.

Legendre, L., Watt, W.D., 1971-1972. On a rapid technique for plankton enumeration. Ann. Inst. Oceanogr. 58, 173-177.

Le Poupon, C., 1994. Automatisation d'un procédé d'analyse de l'azote organique dissous après minéralisation en conditions réductrices. PhD thesis, Univ. Toulon et du Var, France, p. 182.

Liss, P.S., Malin, G., Turner, S.M., 1993. Production of DMS by marine phytoplankton. In: Restelli, G., Angeletti, G. (Eds.), Dimethylsulfide: Oceans, Atmosphere and Climate. Kluwer Academic Publishing, Dordrecht, pp. 1-14.

Lohman, H., 1908. Untersuchungen zur Feststellung des vollstandigen Gehaltes des Meeres an Plankton. Wiss. Meeresunters., Abt. Kiel N. F. 10, 132-170.

Lorenzen, C.J., 1967. Determination of chlorophyll and pheopigments: spectrophotometric equations. Limnol. Oceanogr. 12, $343-346$

Lovelock, J.E., Maggs, R.J., Rasmussen, R.A., 1972. Atmospheric dimethylsulfide and the natural sulfur cycle. Nature $237,452-453$.

Lowry, O.H., Rosebrough, N.J., Farr, A.L., Randall, R.J., 1951. Protein measurement with the Folin phenol reagent. J. Biol. Chem. 193, 265-275.

Milano, J.C., Fache, B., Vernet, J.L., 1990. Corrélation entre l'agitation de la mer et la contamination des moules par les hydrocarbures dans la baie du Lazaret (Toulon, France). J. Rech. Oceanogr. 15, 29-33.

Murphy, J., Riley, J.P., 1962. A modified single solution method for the determination of phosphate in natural waters. Ann. Chem. Acta 27, 31-36.

Porter, K.J., Feig, Y.S., 1980. The use of DAPI for identifying and counting aquatic microflora. Limnol. Oceanogr. $25,943-948$.

Simo, R., 1998. Trace chromatographic analysis of dimethylsulfoxide and related methylated sulfur compounds in natural waters. J. Chromatogr., A 807, 151-164.

Simo, R., Grimalt, J.O., Albaiges, J., 1993. Field sampling and analysis of volatile reduced sulphur compounds in air, water and wet sediments by cryogenic trapping and gas chromatography. J. Chromatogr., A 655, 301-307.

Sournia, A., Belin, C., Berland, B., Erard, E., Gentien, P., Grzebyk, D., Marcaillou, C., Lebaut, C., Lassus, P., Partensky, F., 1991. Le phytoplancton nuisible des côtes de France: de la biologie à la prévention. IFREMER-CNRS Programme National, Efflorescences Algales Marines, p. 154.

Stefels, J., Van Boekel, W.H.M., 1993. Production of DMS from dissolved DMSP in axenic cultures of the marine phytoplankton species Phaeocystis sp.. Mar. Ecol., Prog. Ser. 97, $11-18$.

Steinke, M., Malin, G., Gibb, S.W., Burkill, P.H., 2002. Vertical and temporal variability of DMSP-lyase activity in a coccolithophorid bloom in the northern North Sea. Deep Sea Res. II 49, 3001-3016. 
Sunda, W., Kieber, D.J., Kiene, R.P., Huntzman, S., 2002. An antioxidant function for DMSP in marine algae. Nature 418, $317-320$.

Tang, K.W., 2000. Dynamics of dimethylsulfoniopropionate (DMSP) in a migratory grazer: a laboratory simulation study. J. Exp. Mar. Biol. Ecol. 243, 283-293.

Turner, S.M., Malin, G., Liss, P.S., Harbour, D.S., Holligan, P.M., 1988. The seasonal variation of DMS and DMSP concentrations in nearshore waters. Limnol. Oceanogr. 33, 364-375.

Utermohl, H., 1958. Zur Vervollkommung der quantitativen Phytoplankton-Methodik. Mitt. - Intern. Verein. Theor. Angew. Limnol. 9, 1-38.

Vairavamurthy, A., Andreae, M.O., Iverson, R.L., 1985. Biosynthesis of dimethylsulfide and dimethylsulfoniopropiothetin by Hymenomonas cartarae in relation to sulfur source and salinity variations. Limnol. Oceanogr. 30, 59-70.
Van Duyl, F., Gieskes, W.W.C., Kop, A.J., Lewis, W.E., 1998. Biological control of short-term variations in the concentration of DMSP and DMS during a Phaeocystis spring bloom. J. Sea Res. 40, 221-231.

Van Rijssel, M., Buma, A.N.G., 2002. UVR induced stress does not affect DMSP synthesis in the marine prymnesiophyte Emiliana huxleyi. Aquat. Microb. Ecol. 28, 167-174.

Wang, D.Z., Hzieh, D.P.H., 2002. Effect of nitrate and phosphate on growth and $\mathrm{C} 2$ toxin productivity of Alexandrium tamarense CI01 in culture. Mar. Pollut. Bull. $45,286-289$

White, R.H., 1982. Analysis of dimethylsulfonium compounds in marine algae. J. Mar. Res. 40, 529-536.

Wood, E.D., Armstrong, A.A.J., Richards, F.A., 1967. Determination of nitrate in sea water by cadmium-copper reduction to nitrite. J. Mar. Biol. 47, 23-31. 